\title{
PENINGKATAN KEMAMPUAN PENALARAN MATEMATIK DAN SELF EFFICACY SISWA SMK DENGAN MENGGUNAKAN PENDEKATAN CREATIVE PROBLEM SOLVING
}

\author{
${ }^{1}$ Eka Senjayawati, ${ }^{2}$ Puji Nurfauziah \\ 1ekasenjayawati@ikipsiliwangi.ac.id, 2puji_fauziahahmad@ikipsiliwangi.ac.id \\ ${ }^{1,2}$ Program Studi Pendidikan Matematika, IKIP Siliwangi
}

\begin{abstract}
ABSTRAK
Tujuan penelitian ini adalah untuk menelaah peningkatan kemampuan penalaran matematik antara siswa yang pembelajarannya dengan pendekatan creative problem solving dibandingkan dengan siswa yang pembelajarannya dengan pendekatan konvensional, selain itu menelaah peningkatan kemampuan self efficacy antara siswa yang pembelajarannya dengan pendekatan creative problem solving dibandingkan dengan siswa yang pembelajarannya dengan pendekatan konvensional. Penelitian ini merupakan penelitian kuantitatif dengan metode kuasi eksperimen. Subjek penelitian ini adalah siswa SMK di Kota Cimahi, sampel dipilih menjadi dua kelas yaitu kelas eksperimen dan kelas kontrol. Berdasarkan hasil analisis data didapatkan kesimpulan bahwa peningkatan kemampuan penalaran matematik siswa SMK yang pembelajarannya menggunakan pendekatan creative problem solving lebih baik daripada yang yang menggunakan pembelajaran biasa, serta peningkatan self efficacy siswa SMK yang pembelajarannya menggunakan creative problem solving lebih baik dari pada yang menggunakan pembelajaran biasa.
\end{abstract}

Kata Kunci : pendekatan creative problem solving, penalaran matematik, self efficacy

\begin{abstract}
The purpose of this research is to examine the improvement of mathematical reasoning ability among the students whose learning with creative problem solving approach compared with the students whose learning with conventional approach, besides studying the enhancement of self efficacy ability among the students with the creative problem solving approach compared with the students who study with conventional approach. This research is a quantitative research with quasi experimental method. The subjects of this study were stuents of SMK in Kota Cimahi, the sample was selected into two classes, namely experimental class and control class. Based on the result of data analysis, it is concluded that the improvement of mathematical reasoning ability of vocational students whose learning using creative problem solving approach is better than those using ordinary learning, as well as improving self efficacy of vocational students whose learning using creative problem solving is better than using ordinary learning.
\end{abstract}

Keywords: creative problem solving approach, mathematical reasoning, self efficacy

\section{A. PENdahuluan}

Pada era globalisasi sekarang ini, setiap orang dituntut untuk memiliki kemampuan dalam mengembangkan dan meningkatkan kemampuan dirinya. Hal tersebut dikarenakan daya saing yang meningkat dalam menghadapi MEA (Masyarakat Ekonomi Asean). Menurut Sugiman (2016), tujuan MEA adalah untuk membuka perdagangan bebas dan kerjasama ekonomi. Di dalam mempersiapkan hal tersebut, masyarakat harus memperkuat dirinya dengan berbagai pengetahuan yang menunjang. Artinya pendidikan memegang peranan penting dalam membangun bidang ekonomi, Yaakup (Sugiman, 2016). Di dalam dunia pendidikan sekarang ini, pembelajaran di sekolah tidak daiajarkan seperti dahulu yang berpusat pada guru (teacher center), tetapi sekarang haruslah berfokus pada siswa (student center). Hal tersebut tertuang di dalam kurikulum 2013 yang sekarang ini sedang dilaksanakan. 
Widodo (2015) mengemukakan bahwa guru harus dapat mengimplementasikan kurkulum 2013 di dalam kelas dengan bersungguh-sungguh. Karena kurikulum 2013 berorientasi pada karakteristik kompetensi, yang mencakup sikap, keterampilan dan pengetahuan. Salah satu ciri khas dari kurkulum 2013 adalah pendekatan scientific yang salah satunya adalah mencipta (create), dimana tahapan create tersebut termasuk ke dalam ruang lingkup tingkat perguruan tinggi (Widodo, 2015).

Subjek dari penelitian ini adalah siswa SMK yang sering dikatakan lulusannya untuk langsung terjun ke lapangan. Padahal di lapangan memerlukan pemahaman siswa yang lebih dalam matematika. Siswa harus memiliki penalaran yang cukup baik dalam memahami matematika sebagai bekal ilmu dilapangan. Bicara kemampuan penalaran siswa biasanya dihubungkan dengan cara proses siswa berpikir dengan cara kerja otak korteks berdasarkan bukti-bukti yang ada, hal ini sesuai dengan definisi penalaran, Keraf (1982: 5) menjelaskan penalaran (jalan pikiran atau reasoning) sebagai: "Proses berpikir yang berusaha menghubung-hubungkan fakta-fakta atau evidensi-evidensi yang diketahui menuju kepada suatu kesimpulan”. Dikatakan bahwa kemampuan penalaran menciptakan untuk menarik kesimpulan dari beberapa fakta-fakta yang mendukung siswa untuk menyelesaikan masalah, hal ini dijelaskan dari Sumarmo (2012: 17) berdasarkan penarikan kesimpulan, bahwa kemampuan penalaran dapat di klarifikasikan dengan dua jenis yaitu penalaran induktif dan penalaran deduktif. Biasanya banyak pandangan orang pada umumnya berpendapat bahwa penalaran induktif adalah proses melakukan pengamatan dari khusus ke umum dengan melakukan beberapa percobaan sampai mendapatkan kesimpulan berdasarkan pengamatan sampai mendapat kesimpulan dari hasil pengamatan, dan penalaran deduktif adalah melakukan pernyataan definisi atau pengertian yang sudah kesepekatan untuk menyelesaikan suatu masalah tertentu atau bisa dikatakan dari umum untuk berlaku kepada pernyatan khusus. Namun menurut Sumarmo (2012:17) bahwa penalaran induktif tidak hanya sekedar dari dari khusus ke umum tetapi penalaran induktif memiliki beberapa kegiatan yaitu, a) Penalaran transduktif, b) penalaran analogi yaitu, c) penalaran generalisasi; d) Memperkirakan jawaban; e) memberikan penjelasan terhadap model, fakta, sifat, hubungan atau pola yang ada; $\mathrm{f}$ ) Menggunakan pola hubungan untuk menganalisis situasi, dan menyusun konjektur. Jadi untuk pernyataan khusus ke umum dalam penalaran induktif merupakan bagian dari pengertian dari kegiatan penarik kesimpulan bukan definisi secara umum, dapat saja bahwa hal itu adalah kategori generalisasi. Karena itu untuk melakukan kegiatan penalaran siswa dapat dilakukan berdasarkan keenam item tersebut, jadi kemampuan berpikir penalaran siswa bukan pernyataan tertutup yang menyatakan kepastian menjawab tetapi pernyataan terbuka artinya siswa dapat menyatakan dugaan dari beberapa kemungkinan siswa akan terdorong untuk mencoba dari berbagai jawaban sampai akhirnya mendapatkan kesimpulan. Ini sejalan menurut Suria Sumantri (Jupri, 2004:16) Penalaran adalah suatu proses berpikir dalam menarik kesimpulan yang berupa pengetahuan, kegiatan berpikir yang mempunyai karakteristik tertentu dalam menemukan kebenaran, dan berpikir penalaran memiliki ciri-ciri tertentu.

Selain kemampuan matematik tersebut berdasarkan karakteristik kurikulum 2013 yang harus dikembangkan yaitu sikap. Ketiga karakteristik antara sikap, pengetahuan dan keterampilan tersebut saling terhubung satu dan yang lainnya. Salah satu sikap yang mendukung 
kemampuan kognitif tersebut adalah selfefficacy. Eisenberger, Conti-D'Antonio, Bertrando (Setiadi, 2010) yaitu : (1) mengetahui kemampuan diri, (2) pengendalian kemampuan dan pengetahuan, (3) disiplin diri, (4) mengutamakan penampilan, (5) memprediksi usaha dan motivasi, (6) hasil dari refleksi, dan (7) menghasilkan prestasi. Jika seseorang tidak memiliki dasar self efficacy ia akan menerima tugas baru atau tantangan, dan akan menghambat pekerjaan dimana ia tidak berhasil, dan jika seseorang memiliki self efficacy yang lebih baik, ia akan menerima tugas baru atau tantangan agar memperdalam pengetahuannya, walaupun ia tidak berhasil, ia tidak akan terpengaruh di dalam kinerja (Bandura, 1997). Self efficacy merupakam keyakinan seseorang bahwa ia dapat mengatasi dan menyelesaikan suatu permasalahan yang diperkirakan dapat membuat dia menjadi malu, stres, gagal atau sukses (Nurfauziah, 2012). Maka dapat dikatakan bahwa siswa yang memiliki self efficacy yang bagus, dia siap dalam menghadapi persaingan di tahun masyarakat ekonomi asean ini.

Dalam menguasai dan memahami kemampuan berpikir matematik perlu didukung oleh pendekatan yang inovatif. Pendekatan Creative Problem Solving (CPS) merupakan pendekatan pembelajaran yang difokuskan pada keterampilan siswa dalam memecahkan masalah atau suatu pembelajaran yang berpusat pada keterampilan pemecahan masalah, yang diikuti dengan penguatan kreatifitas. Seperti yang diungkapkan oleh Pepkin (Suryani, 2013:30) bahwa CPS merupakan suatu model pembelajaran yang melakukan pemusatan pada pengajaran dan keterampilan pemecahan masalah, yang diikuti dengan penguatan keterampilan. Tidak hanya dengan cara menghafal tanpa dipikir, keterampilan memecahkan masalah dapat memperluas berpikir kreatif pesertadidik. CPS merupakan variasi pemecahan masalah dengan teknik yang sistematik. Oleh sebab itu peneliti mengambil judul Peningkatan Kemampuan Penalaran Matematik dan Self Efficacy Siswa SMK dengan Pendekatan Creative Problem Solving. Dari paparan diatas, pada penelitian ini diharapkan dapat memberikan kontribusi pada bidang pendidikan khususnya dalam pembelajaran matematika di sekolah dan dapat dijadikan sebagai inovasi baru dalam pembelajaran matematika.

\section{B. KAJIAN TEORI DAN METODE}

A. Kajian Teori

a. Kemampuan Penalaran Matematik

Pengertian kemampuan penalaran siswa biasanya dihubungkan dengan cara proses siswa berpikir dengan cara kerja otak korteks berdasarkan bukti-bukti yang ada, hal ini sesuai dengan definisi penalaran, Keraf (1982: 5) menjelaskan penalaran (jalan pikiran atau reasoning) sebagai: "Proses berpikir yang berusaha menghubung-hubungkan fakta-fakta atau evidensi-evidensi yang diketahui menuju kepada suatu kesimpulan".

Dikatakan bahwa kemampuan penalaran menciptakan untuk menari kesimpulan dari beberapa fakta-fakta yang mendukung siswa untuk menyelesaikan masalah, hal ini dijelaskan dari Sumarmo (2012: 17) berdasarkan penarikan kesimpulan, bahwa kemampuan penalaran dapat di klarifikasikan dengan dua jenis yaitu penalaran induktif dan penalaran deduktif. Biasanya banyak pandangan orang pada umumnya berpendapat bahwa penalaran induktif adalah proses melakukan pengamatan dari khusus ke umum dengan melakukan beberapa percobaan sampai mendapatkan kesimpulan berdasarkan pengamatan sampai mendapat kesimpulan dari hasil pengamatan, dan penalaran deduktif adalah melakukan pernyataan definisi atau pengertian yang sudah kesepekatan untuk menyelesaikan suatu masalah tertentu atau bisa dikatakan dari umum untuk berlaku kepada pernyatan 
khusus, contohnya (Martono, 1999:369) siswa mencoba mencari pembuktian penjumlahan akar-akar dari dari beberapa persamaan kuadrat dari percobaan tersebut siswa dapat menyatakan kesimpulan bahwa setiap persamaan kuadrat dimodelkan matematika dalam bentuk $a x^{2}+b x+c=0, \quad$ didapatkan jumlah akar-akar kuadratnya yaitu $x_{1}+x_{2}=-\frac{b}{a}$, sehingga dari kesimpulan tersebut siswa menduga bahwa rumus tersebut adalah benar maka dari hasil pengamatan umum dapat di gunakan kepada yang lebih khusus ke persamaan kuadrat yang berbeda atau disebut dengan penalaran deduktif. Namun menurut Sumarmo (2012:17) bahwa penalaran induktif tidak hanya sekedar dari dari khusus ke umum tetapi penalaran induktif memiliki beberapa kegiatan yaitu, a) Penalaran transduktif, b) penalaran analogi yaitu, c) penalaran generalisasi; d) Memperkirakan jawaban; e) memberikan penjelasan terhadap model, fakta, sifat, hubungan atau pola yang ada; f) Menggunakan pola hubungan untuk menganalisis situasi, dan menyusun konjektur. Jadi untuk pernyataan khusus ke umum dalam penalaran induktif merupakan bagian dari pengertian dari kegiatan penarik kesimpulan bukan definisi secara umum, dapat saja bahwa hal itu adalah kategori generalisasi. Karena itu untuk melakukan kegiatan penalaran siswa dapat dilakukan berdasarkan keenam item tersebut, jadi kemampuan berpikir penalaran siswa bukan pernyataan tertutup yang menyatakan kepastian menjawab tetapi pernyataan terbuka artinya siswa dapat menyatakan dugaan dari beberapa kemungkinan siswa akan terdorong untuk mencoba dari berbagai jawaban sampai akhirnya mendapatkan kesimpulan. Ini sejalan menurut Suria Sumantri (Jupri, 2004:16) Penalaran adalah suatu proses berpikir dalam menarik kesimpulan yang berupa pengetahuan, kegiatan berpikir yang mempunyai karakteristik tertentu dalam menemukan kebenaran, dan berpikir penalaran memiliki ciri-ciri tertentu.

Dari hasil penjelasan di atas, dapat diambil garis besarnya untuk indikator-indikator kemampuan penalaran untuk melakukan penelitian harus disesuaikan dengan kemampuan penalaran induktif dan deduktif, ini sejalan dengan indikatorindikator kemampuan penalaran matematik (Sumarmo, 2012:16) yaitu,

a. Menarik kesimpulan analogi, generalisasi, dan menyusun konjektur.

b. Menarik kesimpulan logis berdasarkan aturan inferensi, memeriksa validitas argumen, dan menyusun argumen yang valid.

c. Menyusun pembuktian langsung, dan dengan induksi matematik

\section{b. Self-Efficacy}

Self efficacy dapat dikatakan keyakinan seseorang akan kemampuan dirinya di dalam mengorganisir pengetahuannya. Secara bahasa Self efficacy juga dapat dikatan sebagai penilaian diri, penilaian kepribadian, Alwisol (Nurfauziah, 2012). Tetapi self efficacy tidak merujuk pada diri sendiri mengenai harga diri, self efficacy menunjuk pada keyakinan akan kemampuannya untuk meggerakkan motivasi, sumber-sumber kognitif dan serangkaian tindakan yang diperlukan untuk menghadapi tuntutan situasi, Handayani (Nurfauziah, 2012). Teori kognitif Bandura ini memandang bahwa self efficacy berperan sebagai sebuah mekanisme kognitif yang memungkinkan individu mengendalikan reaksi terhadap tekanan, Bandura (Purnamasari, 2014). Teori self efficacy meyakini akan perbedaan kemampuan tiap orang (Bandura, 1997). Dari berbagai pengertian tersebut, dapat dikatakan bahwa self efficacy merupakan keyakinan seseorang akan kemampuan dirinya sehingga ia dapat mengatasi berbagai tekanan atau tuntutan kognitif. 
Karakteristik self efficacy menurut Einsberg, et all (Setiadi, 2010) self efficacy mengacu pada hal-hal berikut:

1. self efficacy mengacu penilaian kemampuan diri,

2. self efficacy mengacu pada mengatur hasil kemampuan dan keterampilan,

3. self efficacy mengacu pada displin diri,

4. self efficacy mengacu pada pencapaian kinerja,

5. self efficacy mengacu pada usaha dan motivasi,

6. self efficacy merupakan produk refleksi,

7. self efficacy menghasilkan pencapaian tujuan.

Di dalam teori Bandura (1997) terdapat empat sumber utama Self-efficacy yaitu antara lain: 1) enactive mastery experiences, 2) vicarious experiences, 3) verbal persuasion and other related social influences, 4) physiological and affective states. Mastery Experience merupakan pengalaman yang nyata yang di dapatkan oleh individu tersebut, diamana ia akan merefleksikan hal-hal apa saja yang dianggap dapat membuat ia gagal ataupun berhasil. Bandura (Setiadi, 2010) mengungkapkan beberapa faktor yang mempengaruhi pengalaman pribadi yaitu: (1) prasangka terhadap kemampuan diri, (2) cara menerima dan menghadapi kesulitan, (3) usaha untuk mendapatkan kemampuan, (4) pengaruh dari orang lain, (5) cara di dalam bertindak, (6) waktu dimana ketika menghadapi kegagalan dan kesuksesan, (7) cara individu di dalam mengatur pengalaman diri nya termasuk didalam proses kemampuan kognitif. Vicarious experience merupakan bagaimana cara seseorang belajar dari dirinya sendiri ataupun dari orang lain. Untuk mendapatkan pengalaman ini, seseorang akan menjadakan orang lain sebagai role model untuk dirinya sendiri (Setiadi, 2010). Verbal persuasion and other related social influences merupakan feedback yang diberikan oleh orang lain atas apa yang telah kita lakukan baik itu positif ataupun negative (Setiadi, 2010). Physiological and affective states merupakan aspek psikologi atau emosi. Bandura (Setiadi, 2010) mengatakan bahwa psikologi berkaitan erat dengan tingkah laku, bagaimana ia bertingkah baik atau buruk akan sesuai dengan tingkat emosinya.

Berdasarkan ciri - ciri atau karakteristik self efficacy, dapat dikatakan bahwa self efficacy memusatkan pada beberapa hal mengenai kemampuan, usaha, performance dan hasil. Hal tersebut sesuai dengan penjabaran Hendriana (Nurfauziah, 2012) bahwa penjabaran dari empat karakteristik Bandura yaitu:

1. percaya pada kemampuan diri,

2. bertindak mandiri dalam mengambil keputusan,

3. memiliki konsep diri yang positif,

4. berani mengungkapkan pendapat.

\section{c. Pendekatan Creative Problem Solving (CPS)}

Pendekatan Creative Problem Solving (CPS) merupakan pendekatan pembelajaran yang difokuskan pada keterampilan siswa dalam memecahkan masalah atau suatu pembelajaran yang berpusat pada keterampilan pemecahan masalah, yang diikuti dengan penguatan kreatifitas. Seperti yang diungkapkan oleh Pepkin (Suryani, 2013:30) bahwa CPS merupakan suatu model pembelajaran yang melakukan pemusatan pada pengajaran dan keterampilan pemecahan masalah, yang diikuti dengan penguatan keterampilan. Tidak hanya dengan cara menghafal tanpa dipikir, keterampilan memecahkan masalah dapat memperluas berpikir kreatif pesertadidik. CPS merupakan variasi pemecahan masalah dengan teknik yang sistematik. Sintaks pembelajaran CPS (Huda, 2014:298):

a. Langkah 1 : Objective Finding; Siswa dibagi kedalam kelompok-kelompok. Siswa mendiskusikan situasi 
permasalahan yang diajukan guru dan membrainstorming sejumlah tujuan atau sasarna yang bisa digunakan untuk kerja kreatif siswa.

b. Langkah 2 : Fact Finding; Siswa membrainstorming semua fakta yang mungkin berkaitan dengan sasaran tersebut.

c. Langkah 3 :Problem Finding; Salah satu aspek kreatifitas adalah mendefinisikan kembali permasalahan agar siswa lebih dekat dengan masalah sehingga memungkinkannya untuk menemukan solusi lebih jelas.

d. Langkah 4 :Idea Finding; Pada langkah ini gagasan siswa didaftar agar terlihat kemungkinan menjadi solusi dari suatu permasalahan. Setelah gagasan terkumpul, sortir gagasan yang potensial dan tidak potensial sebagai solusi. Evaluasi gagasan secara cepat agar menjadi pertimbangan solusi lebih lanjut.

e. Langkah 5: Solution Finding; Gagasan yang memliki potensi terbesar dievaluasi bersama. Salah satu caranya dengan membrainstorming criteria yang dapat menentukan seperti apa solusi terbaik seharusnya. Kriteria ini dievaluasi hingga menghasilkan penilaian secara final.

f. Langkah 6 : Acceptance Finding; Siswa mulai mempertimbangkan isu-isu nyata dengan cara berpikir yang sudah mulai berubah. Siswa diharapkan sudah memiliki cara baru untuk menyelesaikan berbagai masalah secara kreatif . Gagasan-gagasan mereka diharapkan sudah bisa digunakan tidak hanya untuk menyelesaikan masalah tetapi juga untuk mencapai kesuksesan.

\section{Langkah-langkah atau sintaks pembelajaran Creative Problem Solving dalam pembelajaran secara umum dirangkum oleh Suryani (2013:32) adalah sebagai berikut:}

a. Klarifikasi Masalah; Klarifikasi masalah meliputi pemberian penjelasan kepada siswa tentang masalah yang diajukan, agar siswa dapat memahami tentang penyelesaian yang diharapkan.

b. Pengungkapan Gagasan; Siswa dibebaskan untuk mengungkapkan gagasan tentang berbagai macam strategi penyelesaian masalah.

c. Evaluasi dan Seleksi; Setiap kelompok mendiskusikan pendapat-pendapat atau strategi-strategi yang cocok untuk menyelesaikan masalah.

d. Implementasi; Siswa menentukan strategi yang dapat diambil untuk menyelesaikan masalah, kemudian menerapkannya sampai menemukan penyelesaian dari masalah tersebut.

\section{d. Hipotesis Penelitian}

1. Peningkatan kemampuan penalaran matematik antara siswa yang pembelajarannya dengan pendekatan creative problem solving lebih baik daripada siswa yang pembelajarannya dengan pendekatan konvensional?

2. Peningkatan self efficacy antara siswa yang pembelajarannya dengan pendekatan creative problem solving lebih baik daripada siswa yang pembelajarannya dengan pendekatan konvensional?

\section{B. Metode}

Penelitian ini merupakan penelitian kuasi eksperimen karena adanya keterbatasan hal mengkontrol factor-faktor yang kemungkinan dapat mengintervensi situasi pembelajaran yang dilakukan. Disain eksperimen yang digunakan adalah disain kelompok kontrol non-ekuivalen sebagai berikut:

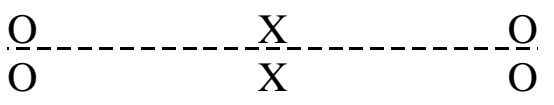

Keterangan:
$\mathrm{O}=$ Pretes $=$ Postes (kemampuan
penalaran matematik)
$\mathrm{X}=$ Pendekatan Creative Problem Solving 
Penelitian ini dilaksanakan di salah satu SMK di kota cimahi yaitu SMK Sangkuriang 1 Cimahi. Penelitian ini dilaksanakan pada bulan Maret hingga bulan Mei tahun 2017.

\section{HASIL DAN PEMBAHASAN}

\section{Analisis Peningkatan Kemampuan Penalaran Matematik}

Untuk mengetahui peningkatan kemampuan penalaran matematik yang belajar menggunakan pendekatan creative problem solving dilakukan beberapa tahapan uji statistik pada data pretes, postes dan $\mathrm{N}$-gain kemampuan penalaran matematik.

Untuk mengetahui signifikansi kesamaan dua rerata skor pretes kemampuan penalaran matematik siswa maka dilakukan uji kesamaan dua rerata, yaitu dengan tahapan uji normalitas, uji homogenitas dan uji kesamaan dua rerata.

\section{Tabel 1}

Hasil Uji Normalitas Pretes Kemampuan Penalaran Matematik

Berdasarkan Tabel 1 didapatkan nilai sig. sebesar 0,200 dan 0,000 pada skoor pretes kelas eksperimen dan kontrol. Karena sig $<0,05$ untuk kelas eksperimen dan kontrol, maka dapat disimpulkan bahwa kedua kelas tidak berdistribusi normal. Karena kedua kelas tidak berdistribusi normal, maka dilanjutkan dengan uji non parametrik Mann Whitney.

Tabel 2

\begin{tabular}{|l|l|l|l|}
\hline \multirow{2}{*}{} & \multicolumn{3}{|l|}{ Kolmogorov-Smirnov ${ }^{\mathrm{a}}$} \\
\cline { 2 - 4 } & Statistic & Df & Sig. \\
\hline Pretes eks & 111 & 35 & $.200^{*}$ \\
Pretes kon & .212 & 35 & .000 \\
\hline
\end{tabular}

Hasil Uji Mann Whitney Pretes Kemampuan Penalaran Matematik

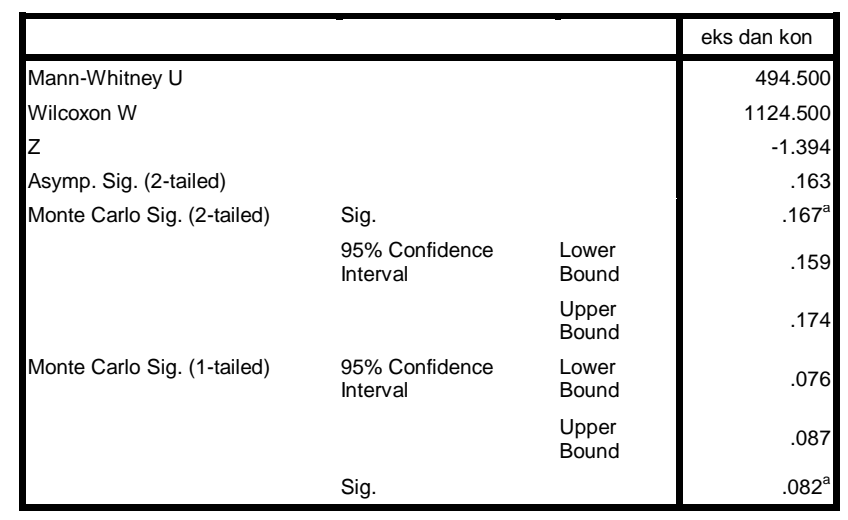

Berdasarkan Tabel 2 pada hasil uji non parametrik Mann Whitney didapatkan nilai sig. sebesar 0,167. Karena sig. > 0,05 maka dapat dikatakan bahwa tidak terdapat perbedaan kemampuan awal penalaran matematik siswa. Karena kedua kelas memiliki kemampuan awal sama maka untuk mengetahui peningkatan kemampuan penalaran matematik siswa yaitu dengan menganalisis data $\mathrm{N}$-gain dengan langkah-langkah yang dilakukan sama dengan langkah-langkah diatas.

\section{Tabel 3}

Hasil Uji Normalitas N-gain kemampuan Penalaran Matematik

\begin{tabular}{|l|l|l|l|}
\hline \multirow{2}{*}{} & \multicolumn{3}{|l|}{ Kolmogorov-Smirnov $^{\mathrm{a}}$} \\
\cline { 2 - 4 } & Statistic & Df & Sig. \\
\hline N-gain Eks & .194 & 35 & .002 \\
N-gain Kon & .137 & 35 & .096 \\
\hline
\end{tabular}

Berdasarkan hasil uji normalitas data Ngain kemampuan penalaran matematik yang terdapat pada Tabel 3 didapatkan nilai sig. 0,002 dan 0,096. Nilai sig. kelas eksperimen $<0,05$ dan kelas kontrol dapat terlihat $>0,05$, hal tersebut berarti bahwa data $\mathrm{N}$-gain kelas eksperimen dan kelas kontrol tidak berdistribusi normal. Karena data tidak berdistribusi normal, maka analisis selanjutnya dilanjutkan dengan uji non parametrik Mann Whitney. 
Tabel 4

Hasil Uji Non Parametrik N-gain Kemampuan Penalaran Matematik

\begin{tabular}{|c|c|c|}
\hline & & $\begin{array}{l}\text { Eks dan } \\
\text { Kon }\end{array}$ \\
\hline \multicolumn{2}{|l|}{ Mann-Whitney U } & 372.500 \\
\hline \multicolumn{2}{|l|}{ Wilcoxon W } & 1002.500 \\
\hline \multicolumn{2}{|l|}{ Z } & -2.843 \\
\hline \multicolumn{2}{|l|}{ Asymp. Sig. (2-tailed) } & .004 \\
\hline \multirow{3}{*}{$\begin{array}{l}\text { Monte Carlo Sig. (2- } \\
\text { tailed) }\end{array}$} & & $.004^{\mathrm{a}}$ \\
\hline & 95\% Confidence Lower Bound & .003 \\
\hline & Upper Bound & .005 \\
\hline \multirow{3}{*}{$\begin{array}{l}\text { Monte Carlo Sig. (1- } \\
\text { tailed) }\end{array}$} & 95\% Confidence Lower Bound & .001 \\
\hline & Upper Bound & .003 \\
\hline & Sig. & $.002^{\mathrm{a}}$ \\
\hline
\end{tabular}

Berdasarkan data diatas pada Tabel 4 dapat dilihat bahwa nilai sig. 0,002. Artinya nilai sig. $<0,05$ dapat diartikan bahwa peningkatan kemampuan penalaran matematik yang belajar menggunakan pendekatan creative problem solving lebih baik daripada peningkatan kemampuan penalaran matenatik siswa yang belajar dengan cara biasa.

\section{Peningkatan Self-efficacy}

Untuk menganalisis peningkatan selfefficacy siswa, yaitu dengan menguji statistik N-gain angket self efficacy siswa. Sebelum dilakukan uji statistik untuk Ngain, maka data angket awal (pretes) harus terlebih dahulu dianalisis untuk mengetahui self efficacy awal siswa. Tahapan uji statistik peningkatan self efficacy sama dengan tahapan untuk menguji peningkatan kemampuan penalaran matematik siswa. Yaitu dengan uji normalitas, homogenitas dan uji t.

\section{Tabel 5}

Hasil Uji Normalitas Angket Awal Self-efficacy

\begin{tabular}{|l|r|r|r|}
\hline \multirow{2}{*}{} & \multicolumn{3}{|c|}{ Kolmogorov-Smirnov ${ }^{\mathrm{a}}$} \\
\cline { 2 - 4 } & Statistic & $\mathrm{df}$ & \multicolumn{1}{c|}{ Sig. } \\
\hline angket awal eks & .185 & 35 & .004 \\
angket awal kon & .115 & 35 & .200 \\
\hline
\end{tabular}

Berdasarkan Tabel 5 pada hasil uji normalitas angket awal self-efficacy siswa, terdapat nilai sig. $<0,05$ pada sig. kelas eksperimen yaitu 0,004 . Sehingga dapat disimpulkan bahwa data tidak berdistribusi normal. Maka untuk analisis selanjutnya yaitu dengan uji non parametrik man whitney.

Tabel 6

Hasil Uji Non Parametrik Angket Awal Selfefficacy

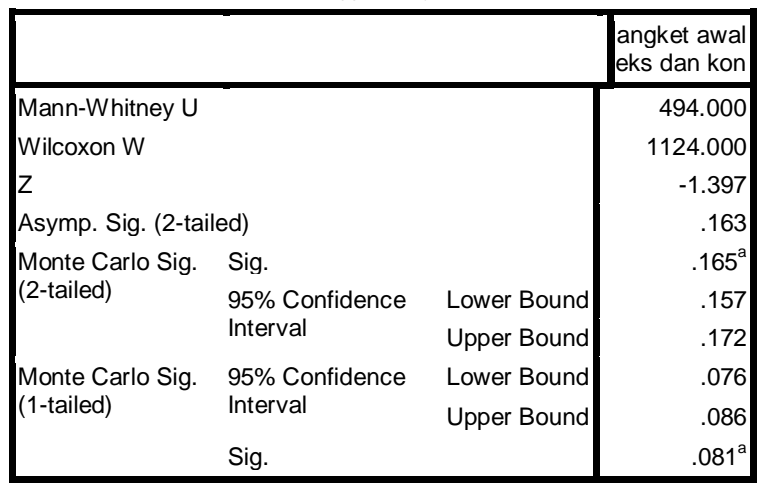

Berdasarkan Tabel 6 pada hasil analisis uji non parametrik didapatkan nilai sig yaitu 0,081 yang berarti bahwa nilai sig tersebut $>0,05$. Dari hasil analisis tersebut dapat disimpulkan tidak terdapat perbedaan awal self efficacy siswa yang pembelajarannya menggunakan pendekatan creative problem solving dari pada siswa yang pembelajarannya dengan menggunakan pembelajaran biasa.

Untuk mengetahui peningkatan self efficacy siswa, maka N-gain angket selfefficacy harus di analisis dengnitas dan cara seperti langkah-langkah sebelumnya yaitu uji normalitas, homogenitas dan uji t, tetapi jika data tidak berdistribusi normal, maka dilanjutkan dengan uji non parametrik, dan jika data berdistribusi normal tetapi tidak homogen, maka dilanjutkan dengan uji t'.

Tabel 7

Hasil Uji Normalitas N-gain Self-efficacy

\begin{tabular}{|l|r|r|r|}
\hline \multirow{2}{*}{} & \multicolumn{3}{|c|}{ Kolmogorov-Smirnov $^{\mathrm{a}}$} \\
\cline { 2 - 4 } & Statistic & \multicolumn{1}{|c|}{$\mathrm{df}$} & \multicolumn{1}{c|}{ Sig. } \\
\hline N-gain Eks & .089 & 35 & .200 \\
N-gain Kon & .295 & 35 & .000 \\
\hline
\end{tabular}

Berdasarkan Tabel 7 pada hasil uji normalitas $\mathrm{N}$-gain self-efficacy siswa, terdapat nilai sig. $<0,05$ pada sig. kelas kontrol yaitu 0,000 . Sehingga dapat disimpulkan bahwa data tidak berdistribusi normal. Maka untuk analisis selanjutnya 
yaitu dengan uji non parametrik man whitney.

Tabel 8

Hasil Uji Non Parametrik N-gain Self-Efficacy

\begin{tabular}{|c|c|c|c|}
\hline & & & $\begin{array}{l}\text { N-gain Eks } \\
\text { dan Kon }\end{array}$ \\
\hline Mann-Whitney U & & & 235.000 \\
\hline Wilcoxon W & & & 865.000 \\
\hline$z$ & & & -4.496 \\
\hline Asymp. Sig. (2-tailed) & & & .000 \\
\hline Monte Carlo Sig. (2- & Sig. & & $.000^{\mathrm{a}}$ \\
\hline & $\begin{array}{l}95 \% \text { Confidence } \\
\text { Interval }\end{array}$ & $\begin{array}{l}\text { Lower } \\
\text { Bound }\end{array}$ & .000 \\
\hline & & $\begin{array}{l}\text { Upper } \\
\text { Bound }\end{array}$ & .000 \\
\hline $\begin{array}{l}\text { Monte Carlo Sig. (1- } \\
\text { tailed) }\end{array}$ & $\begin{array}{l}95 \% \text { Confidence } \\
\text { Interval }\end{array}$ & $\begin{array}{l}\text { Lower } \\
\text { Bound }\end{array}$ & .000 \\
\hline & & $\begin{array}{l}\text { Upper } \\
\text { Bound }\end{array}$ & .000 \\
\hline & Sig. & & $.000^{\mathrm{a}}$ \\
\hline
\end{tabular}

Berdasarkan Tabel 8 pada hasil analisis uji mann whitney didapatkan nilai sig yaitu 0,000 , dan dapat terlihat pula untuk uji monte carlo (1-tailed) nilai sig. adalah 0,000 yang berarti bahwa nilai sig tersebut $<0,05$. Dari hasil analisis tersebut dapat disimpulkan bahwa peningkatan self efficacy siswa yang pembelajarannya menggunakan pendekatan creative problem solving lebih baik dari siswa yang pembelajarannya dengan menggunakan pembelajaran biasa.

Berdasarkan Analis data yang telah dilakukan sebelumnya dapat dilihat bahwa kemampuan penalaran matematik siswa baik pada kelas eksperimen maupun kelas kontrol tidak terdapat perbedaan pada sebelum pembelajaran, artinya kedua kelas memiliki kemampuan yang sama. Pada kelas eksperimen siswa diberikan perlakuan dengan pembelajaran menggunakan pendekatan creative problem solving. Sedangkan kelas kontrol diberikan pembelajaran biasa disesuaikan dengan pembelajaran yang biasa mereka gunakan sehari-hari.

Dalam penelitian ini, kelas eksperimen adalah kelas AP1 yang melakukan kegiatan pembelajaran dengan menggunakan pendekatan creative problem solving. Pada dasarnya pendekatan creative problem solving tidak jauh berbeda dengan pendekatan problem solving, hanya saja pendekatan creative problem solving lebih menekan kan kepada siswa untuk berfikir kreatif (Suryani, 2013). Langkah-langkah pembelajaran creative problem solving yang dilaksanakan di kelas telah sesuai dengan sintaks pembelajaran creative problem solving yang dikemukakan pada BAB II yang meliputi: Objective finding, Fact Finding, Problem Finding, Idea Finding, Solution finding, Acceptance Finding, Evaluation.

Selain kemampuan penalaran matematik yang dianalisis, pada penelitian ini juga dianalisis mengenai peningkatan self efficacy siswa yang pembelajarannya dengan mengunakan pendekatan creative problem solving. Instrumen yang digunakan berupa angket self eficacy yang diadaptasi dari Nurfauziah (2012). Angket diberikan sebelum dilaksanakannya kegiatan pembelajaran (pretes) dan pada akhir pembelajaran. Berdasarkan hasil analisis statistik angket didapatkan bahwa peningkatan self efficacy siswa yang pembelajarannya menggunakan pendekatan creative problem solving lebih baik dari pada siswa yang pembelajarannya menggunakan pembelajara biasa. Artinya terdapat penigkatann self efficacy pada siswa yang pembelajarannya dengan megunakan pendekatan creative problem solving.

Pembelajaran di kelas diawali dengan pembentukan kelompok, siswa dibagi kedalam 9 kelompok besar masing-masing kelompok yaitu 5-6 orang. Kemudian masing-masing siswa di berikan LKS yang digunakan sebagai bahan ajar.

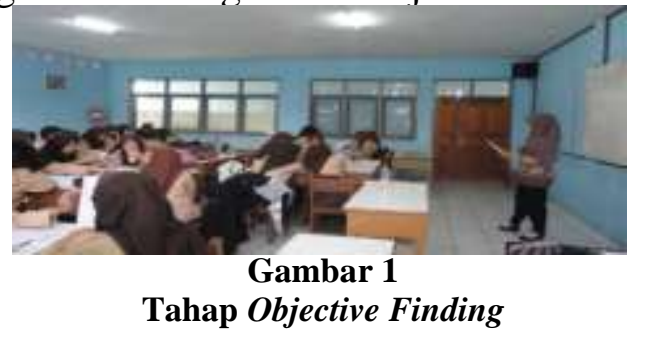


Pada tahap ini, guru menyampaikan tujuan pembelajaran yang akan dilaksanakan, dan memberikan sedikit arahan tentang LKS yang sudah diberikan dan siswa di arahkan untuk menemukan sasaran permasalahan yang ada di dalam LKS. Siswa diberikan stimulus-stimulus oleh guru agar dapat menyelesaikan permasalah yang telah diberikan di dalam LKS dan dapat mengembangkan self-efficacy siswa. Ketika awal kegiatan pembelajaran dengan menggunakan pendekatan creative problem solving, banyak siswa yang mengalami kebingungan di dalam memahami permasalahan yang terdapat di LKS. Karena di dalam kegiatan pembelajaran ini siswa dituntut harus aktif di dalam menemukan ide, solusi, dan menentukan pilihan dari berbagai solusi yang ada untuk menyelesaikan permasalahan. Siswa kesulitan didalam melaksanakan kegiatan pembelajaran karena siswa memang tidak terbiasa dituntut untuk berfikir dengan sistematis. Siswa terbiasa mengandalkan siswa lain yang memang dianggapnya lebih pintar dan potensial di dalam menyelesaikan tugas. Guru terus memberikan motivasimotivasi agar hal tersebut sedikit berkurang dan self-efficacy siswa akan berkembang menjadi lebih baik.

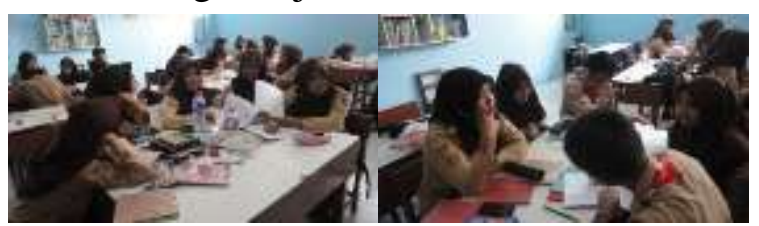

Gambar 2

Tahap Fact Finding dan Problem Finding

Tahap kedua yaitu Fact Finding dan tahap ketiga yaitu Problem Finding. dalam tahap fact finding siswa mencari dan menemukan fakta serta menyelidiki semua materi yang ada di dalam LKS untuk meningkatkan pemahaman mengenai materi yang ingin di identifikasi, kemudian problem finding tahap dimana siswa merumuskan masalah yang ada dalam LKS. Tahap ke empat yaitu Idea Finding, dimana siswa harus menemukan solusi, menemukan ide-ide baru cara-cara yang berbeda untuk menyelsaikan 1 soal yang sama. Pada kegiatan pembelajaran ini materi yang dibahas adalah materi mengenai statistika. Siswa diberikan berbagai permasalahan statistika yang berhubungan dengan kehidupan sehari-hari agar pembelajaran lebih bermakna. Pada umumnya siswa telah mengetahui dasardasar statistika, karena materi tersebut telah dipelajari pada saat sekolah dasar dan sekolah menengah.

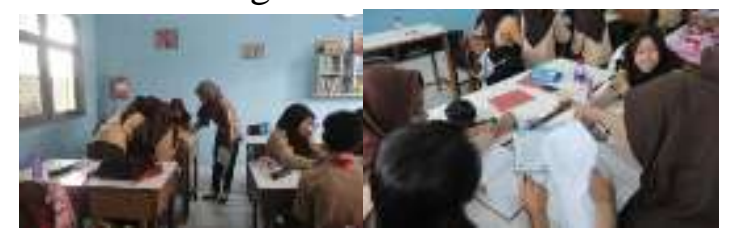

Gambar 3

Tahap Solution Finding dan Acceptance Finding Pada tahap solution finding, setelah siswa menemukan cara-cara berbeda untuk menyelsaikan berbagai macam cara yang ada, sekarang adalah saat nya memilih dan menentukan cara terbaik yang akan digunakan untuk menyelesaikan masalah yang terdapat di dalam LKS. Siswa dituntut untuk percaya akan kemampuan dirinya di dalam menyelesaikan permasalah yang telah diberikan. Dalam hal ini self-efficacy siswa yang baik yang diharapkan muncul, karena dapat memotivasi diri lebih baik lagi dan dapat menjadi motivasi bagi siswa yang lainnya. Kemudian pada tahap selanjutnya yaitu acceptance finding, para siswa bekerja sama dengan kelompoknya menerapkan solusi yang dipilih, solusi tersebut merupakan solusi yang dianggap terbaik berdasarkan hasil diskusi kelompok. Dalam hal ini guru berperan sebagai fasilitator yang memfasilitasi siswa di dalam memberikan arahan dan penjelasan yang tepat agar kegiatan pembelajaran terlaksana dengan baik.

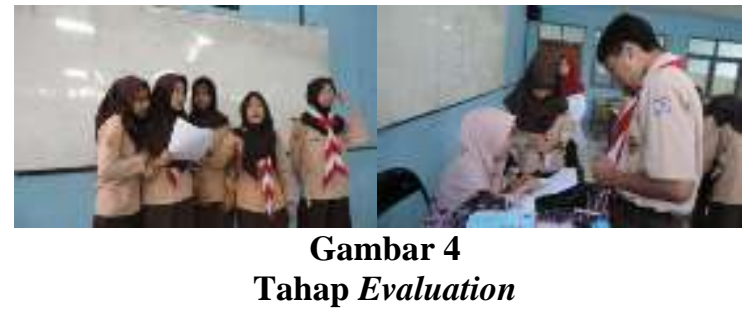


Tahap yang terakhir yaitu Evaluation, dalam tahap ini guru dan siswa bersamasama menyimpulkan materi yang telah dipelajari hari itu dengan membuat ringkasan materi. selanjutnya guru mengoreksi beberapa kesalahan yang muncul pada hasil diskusi dengan melakukan tes lisan 1-2 soal tentang materi yang telah dipelajari. Pada saat itu jga guru memberikan penguatan dan penjelasan materi pembelajaran. Hal tersebut dilakukan untuk meluruskan konsep materi agar tidak terjadi miss concept. Kegiatan pembelajaran dengan menggunakan pendekatan creative problem solving ini dilakukan selama 6 kali pertemuan, karena disesuaikan dengan materi statistika yang dipelajari di sekolah (disesuaikan dengan silabus). Idealnya pendekatan creative problem solving ini diterapkan lebih dari 6 kali pertemuan, agar peningkatan kemampuan penalaran matematik siswa dan self-efficacy siswa dapat terlihat dengan signifikan.

Pada awal kegiatan pembelajaran umumya siswa tidak yakin akan kemampuan dirinya dalam mempelajari matematika. Mereka hanya mengikuti siapa yang menjadi leader di dalam kelas, karena mereka tidak benar paham akan materi sebenarnya. Tetapi setelah diberikan pembelajaran dengan menggunakan pendekatan creative problem solving dan diberikan angket akhir pada pertemuan akhir serta dilakukan wawancara dengan siswa, mereka dapat bertindak secara mandiri di dalam menyelesaikan permasalahan yang diberikan ataupun di dalam mengeluarkan pendapat. Walaupun sebenarnya hasilnya kurang tepat, tetapi proses dari yang tidak mau, tidak berani, dan tidak mampu menjadi bergeser pada kondisi mau, berani dan mampu. Berdasarkan hal tersebut, dapat dikatakan bahwa terdapat peningkatan kemampuan penalaran matematik dan self efficacy siswa SMK yang pembelajarannya dengan menggunakan pendekatan creative problem solving.

Kegiatan pembelajaran matematika di kelas kontrol dilaksanakan di kelas $\mathrm{X}$ ADM 2, kegiatan pembelajaran dilakukan sebanyak 8 kali pertemuan, diantaranya 2 pertemuan (pertemuan ke 1 dan ke 8 ) digunakan untuk mengisi soal pretes (tes awal) dan soal postes (tes akhir) dan 6 pertemuan lainnya adalah diisi dengan kegiatan belajar mengajar biasa dengan menggunakan kurikulum 2013. Kegiatan pembelajaran di kelas kontrol dilaksanakan setiap Rabu dan Jumat, namun karena hari rabu terpotong oleh libur UAS dan UN kelas XII maka pada hari rabu tidak bisa melakukan kegiatan pembelajaran sebagaimana mestinya. Pada akhirnya pembelajaran hanya dapat dilakukan pada hari jumat, sehingga pembelajaran di kelas kontrol memakan waktu sedikit lebih lama daripada kelas eksperimen.

Kegiatan belajar mengajar di kelas kontrol ini menggunakan pembelajaran biasa yang mereka laksanakan yaitu menggunakan kurikulum 2013. Materi yang dipelajari di kelas kontrol ini sama dengan materi yang dipelajari di kelas eksperimen, yaitu mengenai materi statistika. Tetapi di dalam pelaksanaan pembelajaran, kelas kontrol tidak diberikan LKS dengan menggunakan pendekatan creative problem solving. Pada kelas kontrol, sumber belajar yang digunakan adalah buku paket matematika yang biasa mereka gunakan sebelumnnya.

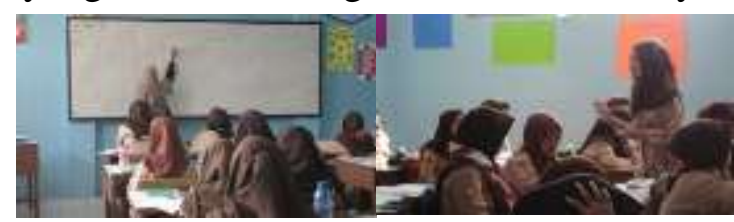

Gambar 5

Kegiatan Pembelajaran di Kelas Kontrol Pada pertemuan pertama, siswa diberikan pretes kemampuan penalaran matematik dan self-efficacy. Untuk pertemuan kedua sampai ketujuh siswa melakukan kegiatan pembelajaran materi statistika dan pada 
pertemuan kedelapan, siswa diberikan postes kemampuan penalaran matematik dan self-efficacy. Tahapan-tahapan dari pembelajaran dengan menggunakan kurikulum 2013 yaitu: 1) mengamati, 2) menanya, 3) mengeksplorasi, 4) menalar, dan 5) mengkomunikasikan. Walaupun siswa telah terbiasa melaksanakan pembelajaran dengan kurikulum 2013, tetapi tetap masih banyak siswa yang berfokus pada siswa lainnya dan guru. Hal tersebut menjadikan siswa tidak mandiri dan tidak percaya pada kemampuan dirinya. Siswa hanya mengandalkan orang lain yang dianggap lebih pintar, dan hal tersebut terjadi pula pada kelas eksperimen. Guru yang bertindak sebagai peneliti harus ekstra memberikan motivasi agar kebiasaan tersebut hilang dan merubah secara sedikit-sedikit pola pikir para siswa tersebut agar self-efficacy siswa meningkat. Karena self-efficacy yang baik dapat meningkatkan prestasi (Bandura, 1997). Di dalam melaksanakan kegiatan belajar mengajar di kelas eksperimen terdapat beberapa kendala, diantaranya adalah: 1) karena hanya dapat melaksanakan pembelajaran setiap hari jumat, maka waktu pembelajaran cukup singkat dan materi perlu diringkas namun intinya tetap tersampaikan dengan jelas, 2) terkadang guru mata pelajaran sebelumnya memakai waktu pembelajaran matematika, sehingga waktu pembelajaran pun terkurangi. Tetapi walaupun terdapat beberapa hambatan, pembelajaran di kelas kontrol ini juga dapat meningkatkan kemampuan penalaran matematik dan selfefficacy siswa. Tetapi peningkatan di kelas kontrol ini memang tidak lebih baik dari kelas eksperimen.

\section{KESIMPULAN}

Berdasarkan analisis data dan pembahasan yang dikemukakan pada Bab IV, dapat diambil beberapa kesimpulan sebagai berkut:

1. Peningkatan kemampuan penalaran matematik antara siswa yang pembelajarannya dengan pendekatan creative problem solving lebih baik daripada siswa yang pembelajarannya dengan pendekatan konvensional.

2. Peningkatan self efficacy antara siswa yang pembelajarannya dengan pendekatan creative problem solving lebiah baik daripada siswa yang pembelajarannya dengan pendekatan konvensional.

\section{DAFTAR PUSTAKA}

Bandura, A. (1995). Self Efficacy : In Changing Societies. United Kingdom: Cambridge University.

Bandura, A. (1997). Self Efficacy: The Exercise of Control. New York: W.H. Freeman.

Barnard, T. (2000). Why Are Proofs Difficult?. Dalam The Mathematical Gazette [Online], Vol. 84, No. 501 (Nov., 2000), pp. 415-422. Tersedia: http://www.jstor.org [13 Februari 2007]

Budiarto, M. T. (2010). Sistem Geometri. Surabaya:UNESA University Press.

Jupri (2004). Pengembangan Desain Pembelajaran Matematika Realistik untuk Menumbuh kembangkan Kemampuan Pemecahan Masalah dan Komunikasi Matematik Siswa. Bandung: Tidak diterbitkan

Keraf, G. (1982). Arguned dan Narasi. Komposisi Lanjutan III. Jakarta: Gramedia.

Martono, K (1999). Kalkulus, Jakarta: Penerbit Erlangga.

Nurfauziah, P. (2012). Peningkatan Kemampuan Koneksi Matematis dan Self Efficacy Siswa SMP Melalui Pembelajaran Matematika 
Model CORE. Tesis SPs UPI: Tidak diterbitkan.

Purnamasari, I. S. (2014). Hubungan Self Efficacy dan Motivasi Berprestasi dengan Kecemasan Mahasiswa yang Sedang Mengerjakan Skripsi. Tesis Univ. Muhammadiyah Surakarta: Tidak diterbitkan.

Rachmawati, E.Y. 2012. Hubungan Antara Self-efficacy dengan Kematangan Karir pada Mahasiswa Tingkat Awal dan Tingkat Akhir di Universitas Surabaya. Calyptra:Jurnal Ilmiah Mahasiswa Universitas Surabaya. [Online]. Tersedia:http://journal.ubaya.ac.id/i ndex.php/jimus/article/view/30. [28 Januari 2016].

Ruseffendi, E.T.(1994). Dasar-Dasar Penelitian dan Pendidikan Bidang Non Eksakta Lainnya. Cetakan Pertama.Semarang. IKIP Semarang Press.

Ruseffendi, E.T. (2006). Pengantar kepada Membantu Guru Mengembangkan Kompetensinya dalam Pengajaran Matematika untuk Meningkatkan CBSA. Bandung:Tarsito

Setiadi, R. (2010). SELF-EFFICACY In Indonesian Literacy Teaching Context: A Theoretical and Empirical Perspective. Bandung: Rizqi Press

Sugiman. 2016. Guru Matematika di Era Masyarakat Ekonomi ASEAN. Materi Seminar Nasional Pendidikan Matematika ULAM Banjarmasin. [online]. Tersedia: http://staff.uny.ac.id/sites/default/fi les/penelitian/sugiman-drs-msidr/2016a-guru-mat-di-eramea.pdf.[3 Januari 2017]
Sumarmo, U. (2012). Bahan Belajar Matakuliah Proses Berfikir Matematik. Bandung: Tidak diterbitkan

Widodo. 2015. Strategi Guru Matematika dalam Menghadapi Asean Economic Community (AEC) 2015 Melalui Implementasi Kurikulum 2013. Prosiding Seminar asional Matematika dan pendidikan Matematika UMS.[online]. Tersedia: https://publikasiilmiah.ums.ac.id/bi tstream/handle/11617/6007/1_16\% 20PROF\%WIDODO.pdf?sequence $=1 \&$ isAllowed=y. [3 Januari 2017] 